\title{
Exploring Perceived Organizational Support to Improve Account Officer Performance
}

\author{
Muhammad Andi Prayogi ${ }^{1^{*}}$, Jufrizen $^{2}$, Muhammad Fahmi $^{3}$, and \\ Muhammad Irfan Nasution ${ }^{4}$ \\ ${ }^{1,2,3,4}$ Faculty of Economics and Business, Universitas Muhammadiyah Sumatera Utara \\ *Email address: \\ muhammadandi@umsu.ac.id
}

\begin{abstract}
The purpose of this study was to identify Perceived Supervisor Support, Quality of Work Life on the performance of Account Officers with Perceived Organizational Support mediation. Data were collected from account officers of Islamic banking in North Sumatra as many as 385 respondents. The data analysis technique uses Structural Equation Modeling with SmartPLS. The results showed that Perceived Supervisor Support, Perceived Organizational Support affect performance, Quality of Work Life has no effect on performance and Perceived Organizational Support, Perceived Supervisor Support has an effect on Perceived Organizational Support, Perceived Organizational Support is an intervening variable between the influence of Perceived Supervisor Support on performance, and Perceived Organizational Support is not an intervening variable between the effect of Quality of Work Life on Account Officer performance. This study contributes to a greater understanding of the mediating role of perceived Perceived Organizational Support on the relationship between Perceived Supervisor Support, Quality of Work Life. Originality This research explores the mediation of Perceived Organizational Support between Perceived Supervisor Support and, Quality of Work Life on Performance, and Perceived Supervisor Support and Perceived Organizational Support are important antecedents in improving Account Officer performance.
\end{abstract}

Keywords: Perceived Supervisor Support, Quality of Work Life, Islamic Banking, SmartPLS.

\begin{abstract}
Abstrak: Tujuan penelitian ini adalah untuk mengidentifikasi Persepsi Dukungan Supervisor (Perceived Supervisor Support), Kualitas Kehidupan Kerja (Quality of Work Life) terhadap kinerja Account Officer dengan mediasi Perceived Organizational Support. Data dikumpulkan dari Account Officer bank syariah di Sumatera Utara sebanyak 385 responden. Teknik analisis data menggunakan Structural Equation Modelling dengan SmartPLS. Hasil penelitian menunjukkan bahwa Perceived Supervisor Support, Perceived Organizational Support berpengaruh terhadap kinerja, Quality of Work Life tidak berpengaruh terhadap kinerja dan Perceived Organizational Support. Perceived Supervisor Support berpengaruh terhadap Perceived Organizational Support, Perceived Organizational Support merupakan variabel intervening antara pengaruh Perceived Supervisor Support terhadap kinerja, dan Perceived Organizational Support bukan variabel intervening antara pengaruh Quality of Work Life pada kinerja Account Officer. Studi ini memberikan kontribusi untuk pemahaman yang lebih besar tentang peran mediasi Perceived Organizational Support yang dirasakan pada hubungan antara Perceived Supervisor
\end{abstract}


Support dan Quality of Work Life. Orisinalitas Penelitian ini mengeksplorasi mediasi Perceived Organizational Support antara Perceived Supervisor Support dan Quality of Work Life pada Kinerja, Perceived Supervisor Support dan Perceived Organizational Support merupakan anteseden penting dalam meningkatkan kinerja Account Officer.

Keywords: Persepsi Dukungan Supervisor, Kualitas Kehidupan Kerja, Perbankan Syariah, Smart PLS.

\section{INTRODUCTION}

To improve the performance of Islamic banking, especially in terms of increasing customers, the employees that banking companies must own are marketing personnel or commonly referred to as Account Officers; without marketing, the public will not know the products offered by banks, every company must have different designations but with the same duties and responsibilities. Account officer in charge of marketing Bank products, both Loan and Funding.

According to (Dahkoul, 2018); (Kusumanegara et al., 2018); (Farisi and Paramita, 2020) employee performance is one of the essential factors that contribute significantly to organizational success; employee performance is predicted to depend on internal satisfaction with his work.

According (Soelton et al., 2020), (Gutserresaa et al., 2020) identified factors that affect performance, including individual performance, quantity, and quality of work, responsibilities, and needs for achievement.

Then (Tarcan et al., 2020); (van Woerkom and Kroon, 2020); (Park et al., 2018) the factor that affects employee performance is perceived supervisor support, where perceived supervisor support includes the relationship between employees and supervisors as one of the verbal commitments or expectations of the parties. Previous research on perceived supervisor support focused on the role of supervisors in the formation of employee extrarole behavior (Ladebo, 2008); (Potipiroon and Faerman, 2020); (Abdullah and Marican, 2020), However, has ignored its effect on employee performance. This study focuses on perceived supervisor support and employee performance; another important idea in this study is how the perceived supervisor suport concept affects employee performance. Theoretically, perceived supervisor support and employee performance positively influence employee performance because employees view that supervisor appreciation will contribute to employee work (Tarcan et al., 2020; Rubel and Kee, 2013), Meanwhile (Tozkoparan and Tenteriz, 2019) determined that perceived supervisor support had no effect on employee performance, but indirectly perceived supervisor support affects individual skills (task performance) (Afzal et al., 2019).

Another factor from the perspective of employee performance that can be used to improve employee performance is the quality of worklife aims to create organizational conditions that can assist employee development to learn. In addition, quality of worklife is a step in human resource management by increasing everyone's confidence to provide optimal performance and feel comfortable and proud to be part of the organization (Dewi et al., 2020) and can improve performance (Nauman et al., 2020). 
The findings of (Hermawati and Mas, 2017) show that quality of worklife directly affects employee performance; Nauman et al. (2020) findings show that quality of worklife is positively related to task performance, contextually and overall. Therefore, this study aims to determine the overall performance of Account officers and assess the impact of quality of worklife on the overall performance dimensions.

Perceived organizational support is one of the critical elements that contribute positively to the achievement of individual results (Eisenberger and Stinglhamber, 2011), employees who feel organizational support will show better performance (Byrne and Hochwater, 2008; Kurtessis et al., 2017). Therefore, the perceived supervisor positively affects perceived organizational support as a power that will be an intervening variable. The research findings provide a better understanding of the relationship between perceived organizational support and perceived organizational support (Eisenberger and Stinglhamber, 2011), then (Santoso et al., 2020); (Dirican and Erdi, 2020) the perceived organizational support variable is accepted to be an intervening variable and a strength in shaping behavior. Then other findings between the POS relationship and performance also have a positive relationship (Imran and Aldaas, 2020); (Rivai and Lukman, 2019).

Although the existing literature shows that perceived supervisor support, Quality of Worklife, and perceived organizational support are distinct but highly interrelated constructs; Little is known about the predictive nature of the supervisor's role in the employee performance literature. Supervisors play an essential role in influencing their subordinates about whether to participate in improving performance. Likewise, quality of worklife will support the process of creating performance improvements. Comprehensively, this research model has never been conducted research that reviews the performance of Islamic Banking Account Officers, based on the gap research that has been stated that this research model has the novelty of previous research related to perceived supervisor support, Quality of Worklife, on employee performance mediated by perceived organizational support.

\section{THEORITICAL REVIEW}

Account Officer Performance. Account officer performance is the result or overall level of success of a person during a specific period in carrying out such as work standards, targets, or other previously agreed criteria (Ridwan et al., 2020) and employee performance must also have a level of individual efficiency and effectiveness to achieve the goal. And organizational goals (Tarcan et al., 2020); (Nasution and Priangkatara, 2022); (Lesmana and Damanik, 2022). Dimensional scales in measuring performance include task, contextual, and adaptive performance. Task performance is related to individual expertise in carrying out work that is directly related to tasks, responsibilities which are a core part of work (Khalid, 2020; Zhang et al., 2020), Then contextual performance refers to behavior that contributes to the culture and climate of the organization, works extra and voluntarily, perseveres with enthusiasm, helps and cooperates with others, and follows organizational rules and procedures. (Guo and Ling, 2020); (Meyers et al., 2020). Adaptive performance refers to Third, adaptive performance is defined as the individual's ability to change the individual's behavior in adjusting to the demands of the work environment, or the individual 
can adjust or adapt to new conditions or unexpected situations. (Kaya and Karatepe, 2020; Tsabiu et al., 2020)

Perceived Supervisor Support. Perceived Supervisor Support is the extent to which employees form an impression on their superiors that their superiors value their contributions, support, and care about their well-being ( Eisenberger and Stinglhamber, 2011). Therefore, supervisor support also represents organizational support, employee perceptions of employees towards supervisors include 1) positive assessment of the organization for the contribution of its supervisors, 2) supervisors influence in providing essential decisions in the organization, 3) autonomy and authority are given by supervisors in carrying out their duties (Eisenberger and Stinglhamber, 2011). While the dimensions for measuring Perceived Organizational Support that has been developed by (Ocampo et al., 2018) include Emotional Support, Instrument Support, role models, Creative Work-Family Management, Perceived Supervisor Support has a positive influence on employee performance because employees view supervisor appreciation as contributing to employee work (Tarcan et al., 2020; Rubel and Kee, 2013), while (Tozkoparan and Tenteriz, 2019) found that it was determined that perceived supervisor support does not affect employee performance. (Tozkoparan and Tenteriz, 2019). Indirectly, perceived supervisor support also affects task performance ) (Afzal et al., 2019).

A positive influence was found between Perceived Supervisor Support and perceived supervisor support based on theory and organizational support (Khan et al., 2015; Sounthary and Vijayalakshmi, 2020), would typically be interpreted to indicate that PSS will show to perceived organizational support ( Eisenberger and Stinglhamber, 2011), Thus, causality may also occur in the opposite direction with perceived organizational support can increase PSS, employee perceptions are more directed to that the organization will appreciate their contribution care about employee welfare. Perceived Supervisor Support is positively related to perceived organizational support (Eisenberger and Stinglhamber, 2011); this indicates that supervisors have an essential role in influencing perceptions of organizational support.

H1: Perceived Supervisor Support has a significant effect on the performance of Account Officers.

H2: Perceived Supervisor Support effects Perceived Organizational Support.

Quality of Work Life. Quality of Work Life is a process of responding to employee needs by developing mechanisms and providing opportunities for employees to plan their worklife. Organizations must ensure Quality of Work Life runs well, such as ensuring employee welfare, job security, job satisfaction, a sound reward system, employee benefits. Moreover, work engagement supports organizational goals (Thakur and Sharma, 2019; PeranginAngin et al., 2016). Then the dimension scale for measuring Quality of Work Life was adopted from (Almarshad, 2015), which has been validated including stress at work, work occupancy, job career and satisfaction, and working conditions. Another factor from an employee performance perspective that can be used as a strategy to improve employee performance is Quality of Worklife (Hermawati and Mas, 2017), explaining that Quality of 
Work Life directly affects employee performance; the findings of (Nauman et al., 2020) show that Quality of Worklife is positively related to task performance, contextually and overall.

H3: Quality of Work Life significantly affects Account Officer performance.

H4. Quality of Work Life significantly affects Perceived Organizational Support.

Mediating Perceived Organizational Support. Perceived Organizational Support is one of the critical elements that contribute positively to the achievement of individual results (Eisenberger and Stinglhamber, 2011), Employees who feel organizational support will show better performance (Kurtessis et al., 2017). Perceived Organizational Support is a feeling from employees that the organization cares, values their contribution, and provides for their social-emotional well-being by giving them respect and support (Afsar and Badir, 2017). The scale for measuring Perceived Organizational support is appreciation, concern and organizational support, opportunities provided by the company, respect, and achievement (Purwaningrum et al., 2020). Perceived Organizational Support can mediate the relationship between perceived supervisor support and quality of work life. Because the theory of organizational support says that employees will form a general perception of the extent to which the organization values their contributions and cares about their welfare (Shahzad et al., 2018).

H5: Perceived Organizational Support has a significant effect on the performance of Account Officers.

H6: Perceived Supervisor Support has a significant effect on the performance of Account Officers mediated by Perceived Organizational Support.

H7: Quality of Work Life has a significant effect on Perceived Organizational Support mediated by Perceived Organizational Support.

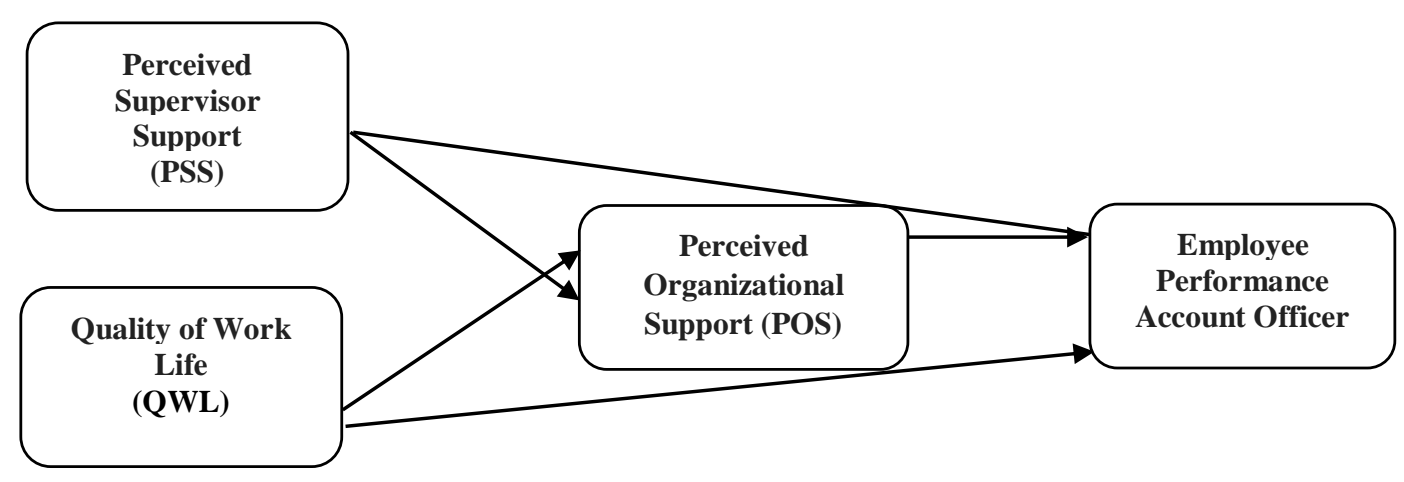

Figure 1. Conceptual Model of Account Officer Performance Improvement 


\section{METHODS}

Sample and Research Procedure. This study involved 385 Sharia Banking Account Officer employees in North Sumatra. This research was conducted from April 2020 to August 2021. This study used an accidental sampling technique due to limitations in reaching Account Officers during the Covid-19 Pandemic so that researchers could take samples of Accounts in which officers are found. Because there is no accurate data on the number of banking Account Officers in North Sumatra, the researchers took a sample based on the Lemeshow formula, where this formula is used if the population cannot be known, the sample is calculated based on Lwanga and Lemeshow. (Lemeshow et al., 1990), sample size calculation for sample proportion estimation as follows:

$$
n=\frac{Z^{2} p(1-p)}{d^{2}}
$$

Note, $\mathrm{n}=$ Number of samples, $\mathrm{Z}=$ Standard Value $=1,96, \mathrm{p}=$ maximum estimate $=50 \%$ $(0,5), d=$ Alpha sampling error $(0,05)$. So the calculation is as follows:

$n=\frac{1.960^{2} \cdot 0.5}{0.10^{2} \cdot 0.5}=384,16$

obtained a sample of 385 Islamic banking account officers in North Sumatra, Indonesia.

Questionnaire and measures. To reach Account Officers in North Sumatra, a structured questionnaire was given to collect primary data on respondents. To request a response from respondents, the questionnaire uses a Likert scale with criteria number 1 (strongly disagree) 2 (disagree) 3 (disagree), 4 (agree), 5 (strongly disagree). The statements in the questionnaire were all answered by respondents consisting of 14 statements of Perceived Supervisor Support with 4 (four) dimensions, namely: Emotional Support, Instrumental Support, Role Model, Creative work-family management. Quality of Work Life consists of 16 questions with seven dimensions: Health and safety, Economic and family needs, Social needs, Esteem, Actualization, Knowledge, Aesthetics. Perceived Organizational Support as many as 16 statements. There are 23 employee performance statements, consisting of Task Performance, Adaptive Performance, Contextual Performance. Before the questionnaire was given to the respondents, the validity and reliability of the questionnaire were tested first, by giving it to 30 respondents from Islamic Non-Banking Account Officers in Medan City, after obtaining the results from the 30 respondents, then continued with a validity test using Product Moment Correlation, and all the results obtained the instrument is declared valid because of the p-value is less than 0.05 . Valid instruments were then tested for reliability, and the results of the reliability test using Cronbach Alpha obtained the Perceived Supervisor Support value of 0.91, Quality of Work Life of 0.92, Perceived Organizational Support of 0.93, and Employee Performance of 0.91, all variables can be declared reliable or meet Cronbach's alpha because it has a value is greater than 0.7 .

Data Analysis Technique. This quantitative study was carried out using standard research procedures, which were collected into a single unit into a diagnostic tool using Structural Equation Modelling using SmartPLS. 


\section{RESULTS}

After the questionnaires were collected, as many as 385 complete respondents, it can be explained that the demographics of the respondents consisted of 60 percent being male and 40 percent female. Based on age consisting of 29.88 percent are 25 to 30 years, 21.29 percent are 31 to 35 years, 20 percent are 36 to 40 years, 16.37 percent are 41 to 45 years, and 12.46 percent are is less than 46 Year. Based on education level, 9.88 percent are D3, 70.12 percent are Bachelors (S1), 20 percent are Masters (S2). Based on status, 70 percent are married, 30 percent are unmarried. Having work experience, 19.74 percent are under three years, 32.73 percent are 3-5 years, 30.65 percent are 6-10 years, 16.88 percent are above 11 years.

Table 1. Distribution of Respondents by their Socio Demographic Characteristics

\begin{tabular}{llcc}
\hline \multicolumn{1}{c}{ Demografi } & \multicolumn{1}{c}{ Category } & Frequency & Percentage \\
\hline Sex & Male & 231 & 60 \\
Age & Female & 154 & 40 \\
& $25-30$ & 115 & 29.88 \\
& $31-35$ & 82 & 21.29 \\
\multirow{5}{*}{ Educational Qualification } & 77 & 20 \\
& $36-40$ & 63 & 16.37 \\
\multirow{5}{*}{ Marital Status } & $41-45$ & 48 & 12.46 \\
\multirow{3}{*}{ Working period } & Associate degree (D3) & 38 & 9.8 \\
& Bachelor (S1) & 270 & 70.12 \\
& Master (S2) & 77 & 20 \\
& Married & 269 & 70 \\
& Unmarried & 116 & 30 \\
& 1 - 3 Years & 76 & 19.74 \\
& 3 - 5 Years & 126 & 32.73 \\
& 6- 10 Years & 118 & 30.65 \\
\hline
\end{tabular}

Measurement. The measurement of this research model uses the Outer model analysis. This model specifies the relationship between latent variables and their indicators. Alternatively, it can be said that the outer model defines how each indicator relates to its latent variables. Tests performed on the outer model: 1). Convergent Validity. The value of convergent validity is the value of the loading factor on the latent variable with its indicators. Expected value >0.7. 2). Discriminant Validity. This value is the value of the cross-loading factor that is useful for determining whether the construct has an adequate discriminant, namely by comparing the loading value on the intended construct, which must be greater than the loading value with other constructs. 4). Average Variance Extracted (AVE). The expected AVE value exceeds the number > 0.5. 5). Composite Reliability. Data that has composite reliability $>0.7$ has high reliability. 6). Cronbach Alpha. Cronbach Alpha strengthened the reliability test. Value is expected to exceed number $>0.6$ for all constructs. Convergent Validity Test (Convergent Validity). The following is a picture of the results of the PLS Algorithm calculation, then the value of the loading factor indicators for each variable is seen: 


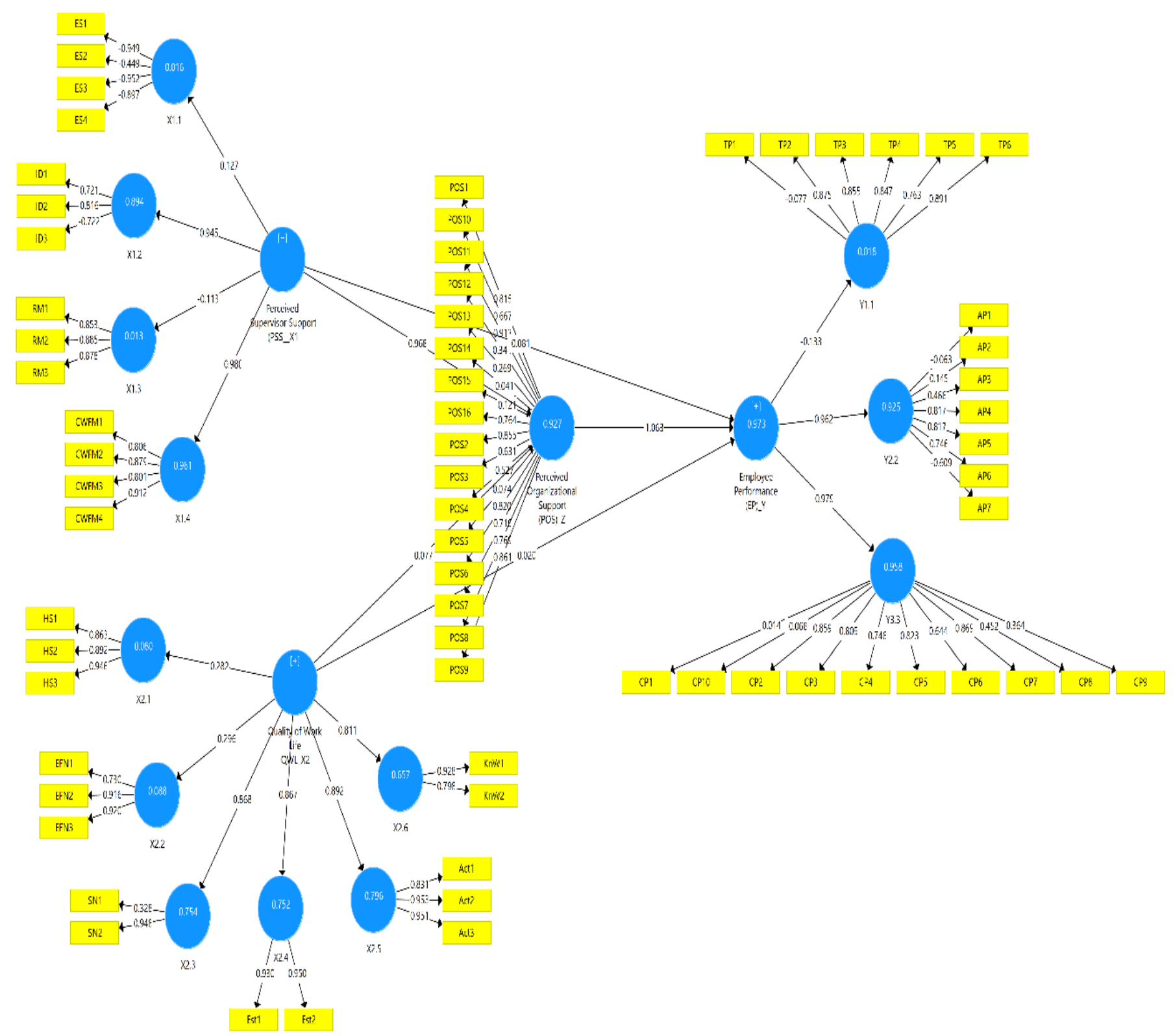

Figure 2. Outer model (PLS Algorithm Model 1)

In the results of the PLS Algorithm, some indicators do not meet the assumptions, where the value of internal consistency, namely the high value of composite reliability, shows the consistency value of each indicator in measuring the construct. Expected CR value $>0.7$. In the perceived supervisor support variable, the indicator that does not meet the criteria is Emotional Support (ES) 2. The Quality of Work Life variable that does not meet the criteria is X2: Social Need (SN) 1 and Dimensions and their Aesthetic indicators. (Aes1, Aes2). Organizational Support Variables (Perceived Organizational Support) that do not meet the criteria consist of POS 3, POS4, POS5, POS10, POS12, POS13, POS14, POS15. Employee Performance variables that do not meet the criteria are Task erformance 
(TP1), Adaptive performance (AP1), AP2 AP7, and Contextual Performance (CP) 1, CP8, CP10. This indicator cannot be used in this study because it does not meet the outer loading value of 0.7 and must be eliminated from the research model. The results after the elimination.

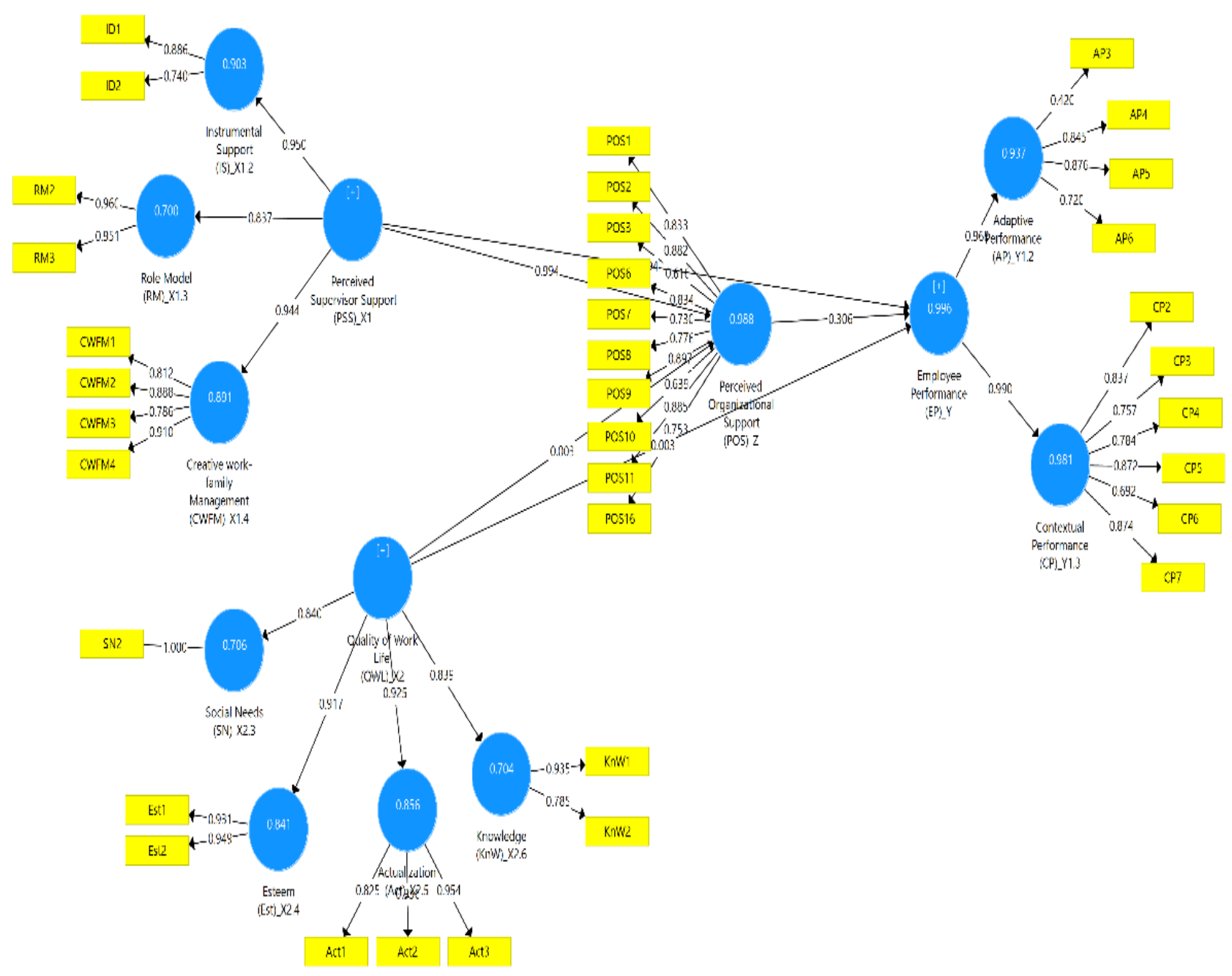

Figure 3. Outer model (PLS Algorithm Model 2)

Convergent Validity. After being eliminated from the research model, the calculation is carried out again, the results of the PLS Algorithm are obtained that meet the outer loading criteria and meet the AVE value. The results of the PLS Algorithm of the PLS model can be seen that the value of the loading factor of the indicators on each variable is not below 0.6. Thus, the analysis is continued on the Discriminant Validity test. The results of the PLS Algorithm, which can be seen in Figure 2, show that all indicators of all variables have a loading value greater than 0.70 . This means that they have a high level of validity, thus 
meeting convergent validity. The results of the calculation of the outer loading value of each indicator on the research variables are as follows:

Table 2. Measurement model

\begin{tabular}{|c|c|c|c|c|c|}
\hline Construct & Indicator & $\begin{array}{l}\text { Loading } \\
\text { Factor }\end{array}$ & $\alpha$ & CR & AVE \\
\hline \multirow{3}{*}{$\begin{array}{l}\text { Perceived Supervisor Support } \\
\text { Emotional Support }\end{array}$} & & & 0.91 & 0.94 & 0.63 \\
\hline & ES2 & 0.963 & & & \\
\hline & ES4 & 0.880 & & & \\
\hline \multirow{2}{*}{ Instrumental Support } & ID1 & 0.886 & & & \\
\hline & ID2 & 0.740 & & & \\
\hline \multirow[t]{2}{*}{ Role Model } & RM2 & 0.960 & & & \\
\hline & RM3 & 0.951 & & & \\
\hline Creative work-family & CWFM1 & 0.812 & & & \\
\hline \multirow[t]{3}{*}{ Management } & CWFM2 & 0.888 & & & \\
\hline & CWFM3 & 0.786 & & & \\
\hline & CWFM4 & 0.910 & & & \\
\hline Quality of Work Life & & & 0.93 & 0.93 & 0.93 \\
\hline Social needs & $\mathrm{SN} 2$ & 1.000 & & & \\
\hline \multirow{2}{*}{ Esteem } & Est1 & 0.931 & & & \\
\hline & Est2 & 0.949 & & & \\
\hline \multirow[t]{3}{*}{ Actualization } & Act1 & 0.825 & & & \\
\hline & Act2 & 0.956 & & & \\
\hline & Act2 & 0.954 & & & \\
\hline \multirow{2}{*}{ Knowledge } & KnW1 & 0.937 & & & \\
\hline & KnW2 & 0.782 & & & \\
\hline \multirow[t]{10}{*}{$\begin{array}{l}\text { Perceived Organzational } \\
\text { Support (POS) }\end{array}$} & & & 0.93 & 0.90 & 0.62 \\
\hline & POS 1 & 0.883 & & & \\
\hline & POS 2 & 0.882 & & & \\
\hline & POS 3 & 0.617 & & & \\
\hline & POS 6 & 0.834 & & & \\
\hline & POS 7 & 0.729 & & & \\
\hline & POS 8 & 0.776 & & & \\
\hline & POS 9 & 0.897 & & & \\
\hline & POS 11 & 0.885 & & & \\
\hline & POS 16 & 0.753 & & & \\
\hline Account Officer Performance & & & 0.91 & 0.93 & 0.58 \\
\hline \multirow[t]{3}{*}{ Adaptive Performance } & AP3 & 0.861 & & & \\
\hline & AP4 & 0.853 & & & \\
\hline & AP5 & 0.760 & & & \\
\hline \multirow[t]{7}{*}{ Contextual Performance } & AP6 & 0.889 & & & \\
\hline & $\mathrm{CP} 2$ & 0.838 & & & \\
\hline & $\mathrm{CP} 3$ & 0.757 & & & \\
\hline & CP4 & 0.783 & & & \\
\hline & CP5 & 0.873 & & & \\
\hline & CP6 & 0.691 & & & \\
\hline & $\mathrm{CP} 7$ & 0.874 & & & \\
\hline
\end{tabular}

Note : Cronbach's Alpha ( $\alpha$ ), Composite Reliability (CR); Average Variance Extracted (AVE) 
Based on the data presented in Table 2 it is known that each research variable indicator has an outer loading value $>0.7$. If an outer loading value between $0.5-0.6$ is considered sufficient to meet the convergent validity requirements. Table 2 data shows that there are no indicator variables whose extreme loading values are below 0.5 , so all indicators are declared feasible or valid for research use and can be used for further analysis with the Discriminant Validity test, which aims to ensure that each concept of each construct or latent variable is different from other variables.

Table 3. Cross Loading (Discriminant Validity)

\begin{tabular}{|c|c|c|c|c|}
\hline & $\begin{array}{c}\text { Perceived } \\
\text { Supervisor } \\
\text { Support_(PSS)_X1 }\end{array}$ & $\begin{array}{l}\text { Quality of Work } \\
\text { Life_(QWL)_X2 }\end{array}$ & $\begin{array}{c}\text { Perceived } \\
\text { Organizational } \\
\text { Support_(POS)_Z }\end{array}$ & $\begin{array}{c}\text { Employee } \\
\text { Performance_(EP)_Y_ }\end{array}$ \\
\hline ID1 & 0.90 & -0.03 & 0.88 & 0.90 \\
\hline ID2 & 0.62 & -0.02 & 0.62 & 0.63 \\
\hline RM2 & 0.84 & -0.04 & 0.83 & 0.83 \\
\hline RM3 & 0.76 & -0.03 & 0.73 & 0.75 \\
\hline CWFM1 & 0.79 & -0.06 & 0.78 & 0.81 \\
\hline CWFM2 & 0.88 & -0.01 & 0.90 & 0.87 \\
\hline CWFM3 & 0.67 & 0.00 & 0.64 & 0.65 \\
\hline CWFM4 & 0.86 & -0.01 & 0.88 & 0.86 \\
\hline SN2 & -0.02 & 0.84 & -0.02 & -0.03 \\
\hline Est1 & 0.00 & 0.80 & 0.01 & 0.00 \\
\hline Est2 & $-0,04$ & 0.92 & -0.03 & -0.04 \\
\hline Act1 & $-0,02$ & 0.87 & -0.02 & -0.02 \\
\hline Act2 & -0.04 & 0.83 & -0.03 & -0.04 \\
\hline Act3 & -0.03 & 0.83 & -0.02 & -0.03 \\
\hline KnW1 & -0.04 & 0.88 & -0.04 & -0.04 \\
\hline KnW2 & -0.01 & 0.50 & -0.02 & -0.01 \\
\hline POS1 & 0.79 & -0.04 & 0.83 & 0.82 \\
\hline POS2 & 0.90 & -0.03 & 0.88 & 0.90 \\
\hline POS3 & 0.62 & -0.02 & 0.62 & 0.63 \\
\hline POS6 & 0.84 & -0.04 & 0.83 & 0.83 \\
\hline POS7 & 0.76 & -0.03 & 0.73 & 0.75 \\
\hline POS8 & 0.79 & -0.06 & 0.78 & 0.81 \\
\hline POS9 & 0.88 & -0.01 & 0.90 & 0.87 \\
\hline POS10 & 0.67 & 0.00 & 0.64 & 0.65 \\
\hline POS11 & 0.86 & -0.01 & 0.88 & 0.86 \\
\hline POS16 & 0.70 & 0.02 & 0.75 & 0.70 \\
\hline AP3 & 0.39 & -0.01 & 0.34 & 0.39 \\
\hline AP4 & 0.79 & -0.04 & 0.83 & 0.82 \\
\hline AP5 & 0.90 & -0.03 & 0.88 & 0.90 \\
\hline AP6 & 0.62 & -0.02 & 0.62 & 0.63 \\
\hline CP2 & 0.84 & -0.04 & 0.83 & 0.83 \\
\hline CP3 & 0.76 & -0.03 & 0.73 & 0.75 \\
\hline CP4 & 0.79 & -0.06 & 0.78 & 0.81 \\
\hline CP5 & 0.88 & -0.01 & 0.90 & 0.87 \\
\hline CP6 & 0.67 & 0.00 & 0.64 & 0.65 \\
\hline CP7 & 0.86 & -0.01 & 0.88 & 0.86 \\
\hline
\end{tabular}

Table 3 shows the cross-loading value of each indicator in the research variable, which has the most significant cross-loading value for the variables it has formed compared to the 
cross-loading values for other variables. Based on the results obtained, it can be stated that the indicators used in this study have good discriminant validity in compiling their respective variables. Next, by looking at the Average variant extracted (AVE) value in Table 2 , which shows that the AVE value is more significant than 0.50 , there is no convergent validity problem in the model being tested. Then calculate the composite reliability (CR) value; in Table 2, the composite reliability (CR) value of all research variables is greater than 0.6, this indicates that each variable has met composite reliability, it can be concluded that all variables have a high level of reliability. Table 2 shows the Cronbach alpha value > 0.7 , meaning that all variables in this study have met the reliability.

Inner Model Analysis. Inner Model analysis or structural model evaluation can be done with three analyses: $\mathrm{R}^{2}, \mathrm{Q}^{2}$, and $\mathrm{F}^{2}$. The value of $\mathrm{R}^{2}$ shows the level of determination of the exogenous variable to the endogenous variable. The greater the $\mathrm{R}^{2}$ value, the better the level of determination.

Table 4. Determinant Coefficient of PLS Method

\begin{tabular}{lcc}
\hline & R Square & R Square Adjusted \\
\hline Perceived Organizational & 0.99 & 0.99 \\
Support_(POS)_Z & 1.00 & 90 \\
Employee Performance_Y & & 90 \\
\hline
\end{tabular}

The value of R Square is the coefficient of determination on the endogenous construct. $\mathrm{R}$ square values are 0.67 (strong), 0.33 (moderate) and 0.19 (weak). The value of $\mathrm{R}$ Square in this study looks 0.99 , which means strong. The goodness of fit assessment is known from the Q-Square value. The Q-Square value has the same meaning as the coefficient determination (R-Square) in regression analysis, where the higher the Q-Square, the model can be said to be better or more fit with the data. The results of the calculation of the Qsquare value are as follows: $\mathrm{Q}$ Square $=1-\left[\left(1-\mathrm{R}_{1}{ }^{2}\right) \times\left(1-\mathrm{R}_{2}{ }^{2}\right)\right]=1-[(1-0.99) \times(1-0.89)]=$ $1-(0.01 \times 0.11)=1-0.0011=0.9989$. Obtained a $Q-S q u a r e$ value of $0,0.99999681$. This shows that the diversity of the research data that the research model can explain is $999.89 \%$. At the same time, the remaining $0.11 \%$ is explained by other factors outside the research model. Thus, this research model can be declared to have good goodness of fit from these results.

Table 5. F-Square $\left(\mathrm{F}^{2}\right)$ results for effect size

\begin{tabular}{|c|c|c|c|c|}
\hline & $\begin{array}{l}\text { Employee } \\
\text { Performance }\end{array}$ & $\begin{array}{l}\text { Perceived } \\
\text { Organizational } \\
\text { Support_(POS }\end{array}$ & $\begin{array}{c}\text { Perceived } \\
\text { Supervisor } \\
\text { Support_(PSS } \\
\end{array}$ & $\begin{array}{l}\text { Quality of } \\
\text { Work Life } \\
\text { _(QWL)_X2 }\end{array}$ \\
\hline $\begin{array}{l}\text { Perceived Supervisor } \\
\text { Support_(PSS)_X1 }\end{array}$ & 1.62 & 82.41 & & \\
\hline $\begin{array}{l}\text { Quality of Work Life } \\
\text { (QWL)_X2 }\end{array}$ & 0.00 & 0.00 & & \\
\hline $\begin{array}{l}\text { Perceived } \\
\text { Organizational }\end{array}$ & 0.32 & & & \\
\hline $\begin{array}{l}\text { Support_(POS)_Z } \\
\text { Employee } \\
\text { Performance_(EP)_Y }\end{array}$ & & & & \\
\hline
\end{tabular}


For the F-Square results based on table 5, it can be stated that the effect of Perceived Supervisor Support on Employee Performance has an $\mathrm{F}^{2}$ of 1.62 which means that $(1,335)$ chooses a strong influence. Quality of Work Life to Employee Performance has F2 of (0.000), which means it has no effect. Perceived Organizational Support against Employee Performance user has a large $\mathrm{F}^{2}(0.32)$. Perceived Supervisor Support against Perceived Organizational Support has an $\mathrm{F}^{2}$ value of 82.41, meaning that it has a strong effect. Quality of Work Life on Perceived Organizational Support having a value of 0.00 is considered to have no effect.

Bootstrapping Results (Hypothesis Testing). The test results using the bootstrapping method from the SEM-PLS analysis are as follows:

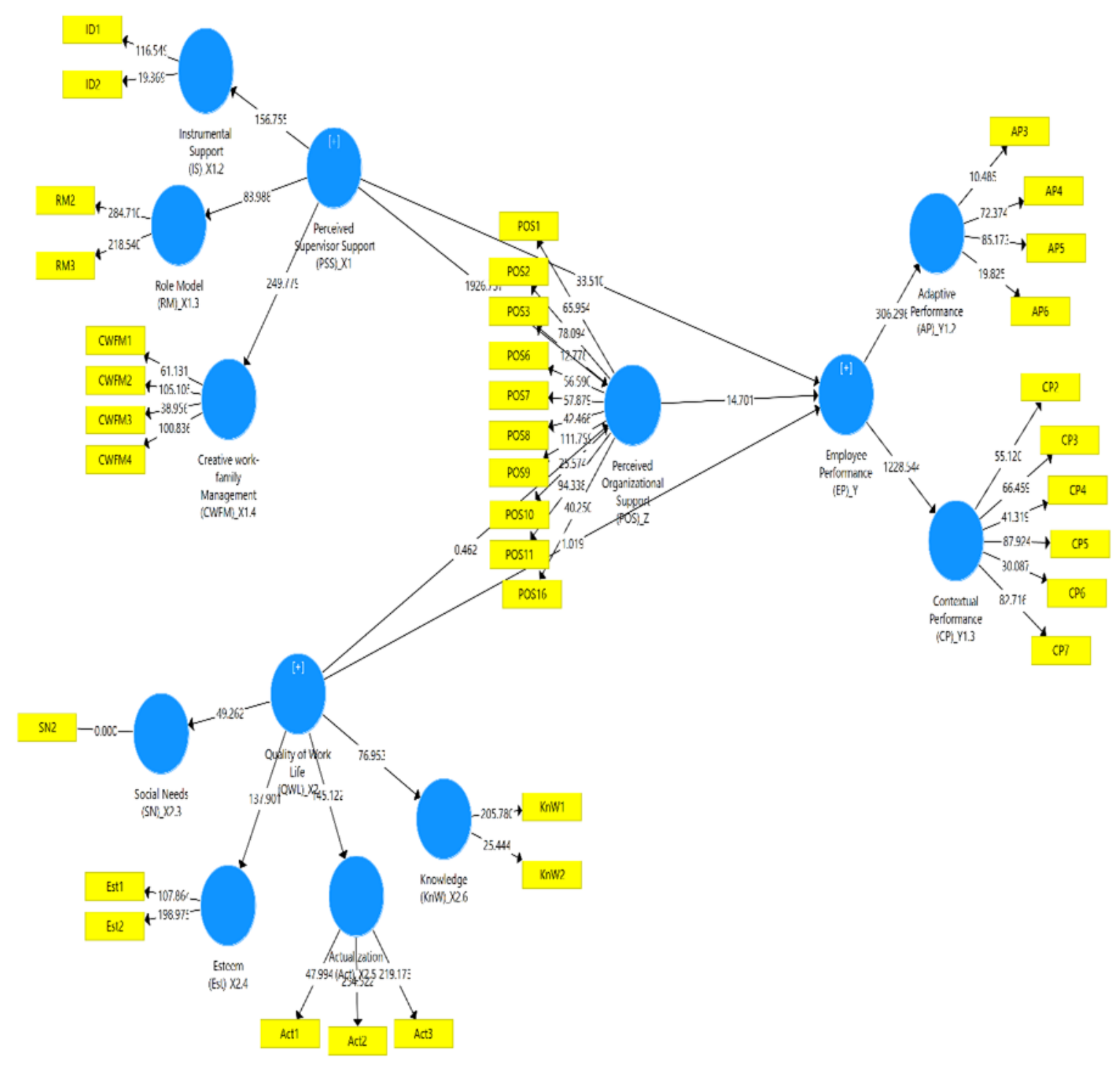

Figure 4. Islamic Banking Account Officer Performance Improvement Model 
Based on the inner model schema is shown in Figure 3, it can be explained that the most significant path coefficient value is indicated by the effect of Perceived Supervisor Support (PSS) on employee performance of 33,510. Then the second most significant influence is the effect of perceived organizational support on employee performance of 14.701, and the most miniature effect is shown by the effect of quality of work-life on employee performance of 1.01. The description of these results shows that all variables in this model have a path coefficient with a positive number. This shows that the greater the path coefficient value on one independent variable on the dependent variable, the stronger the influence between the independent variables on the dependent variable.

Based on the results of the Bootstrapping data that has been done, the results can be used to answer the hypothesis in this study. Hypothesis testing in this study was conducted by looking at the value of T-Statistics and P-Values. The research hypothesis can be declared accepted if the P-Values $<0.05$. The calculation results can be seen based on direct, indirect, and total effects. The results of hypothesis testing obtained in this study through the inner model:

Table 6. Hypothesis Test Results

\begin{tabular}{lccccc}
\hline \multicolumn{1}{c}{ Hipotesis } & $\begin{array}{c}\text { Sample } \\
\text { Mean } \\
(\mathbf{M})\end{array}$ & $\begin{array}{c}\text { Standard } \\
\text { Deviation } \\
(\text { STDEV })\end{array}$ & $\begin{array}{c}\text { T Statistics } \\
(\mid \mathbf{O} / \text { STDEV|) }\end{array}$ & $\begin{array}{c}\text { P } \\
\text { Values }\end{array}$ & Hasil \\
\hline H1: PSS $\rightarrow$ EP & 0.69 & 0.02 & 32.51 & 0.00 & Accepted \\
H2: QWL $\rightarrow$ EP & 0.00 & 0.00 & 0.96 & 0.34 & Rejected \\
H3: POS $\rightarrow$ EP & 0.31 & 0.02 & 14.24 & 0.00 & Accepted \\
H4: PSS $\rightarrow$ POS & 0.99 & 0.00 & 1933.77 & 0.00 & Accepted \\
H5: QWL $\rightarrow$ POS & 0.00 & 0.01 & 0.49 & 0.63 & Rejected \\
H6: PSS $\rightarrow$ POS $\rightarrow$ EP & 0.31 & 0.02 & 14.21 & 0.00 & Accepted \\
H7: QWL $\rightarrow$ POS $\rightarrow$ EP & 0.00 & 0.00 & 0.48 & 0.63 & Rejected \\
\hline
\end{tabular}

Note: Perceived Supervisor Support_(PSS), Quality of Work Life _(QWL), Perceived Organizational Support_(POS) and Employee Performance (EP).

So the results in Table 5 can be stated as follows: Perceived Supervisor Support_on Employee Performance has a significant effect with a p-value of 0.00 is less than 0.05 . Quality of Work Life on Employee Performance has no significant effect with a p-value of 0.34 is less than 0.05. Perceived Organizational Support on Employee Performance has a significant effect with $\mathrm{p}$ Value 0.00 is less than 0.05. Perceived Supervisor Support on Perceived Organizational Support_ has a significant effect with a p-value of 0.00 is less than 0.05. Quality of Work Life on Perceived Organizational Support has no effect with a pvalue of 0.63 is greater than 0.05. Perceived Supervisor Support on Employee Performance mediated Perceived Organizational Support shows a p-value of 0.00 is less than 0.05, which means that there is an indirect effect, which means that Perceived organizational support as a variable intervention. Quality of Work Life on Employee Performance mediated by Perceived Organizational Support shows a p-value of 0.63 is greater than 0.05 . This means that there is no indirect effect, meaning that Perceived organizational support is not an intervening variable. The effect of the total effect is also stated that the results of this study have a finding that Perceived Supervisor Support in total has a significant effect on 
Employee Performance with a p-value of 0.00 is less than 0.05. Quality of Work Life in total has no significant effect on Employee Performance with p-value 0.55 is greater than 0.05 Perceived Organizational Support in total has a significant effect on Employee Performance with p-value 0.00 is less than 0.05 Perceived Supervisor Support in total has a significant effect on Perceived Organizational Support with a p-value 0.00 is less than 0.05 . Quality of Work Life in total has no significant effect on Perceived Organizational Support p-value 0.63 is greater than 0.05 .

\section{DISCUSSION}

The findings in this study prove a significant influence between Perceived Supervisor Support on the Performance of Islamic Banking Account Officers in North Sumatra. This effect shows that the higher the support provided by the Supervisor will further improve the performance of the Account Officer, where the Account officer must get support from the Supervisor, the primary support that must be received is Instrumental Support, where the Supervisor will always assist the account officer if he faces problems at work. The following support is a reliable supervisor if there are problems and the Account Officer's responsibilities cannot be resolved outside of work. This is a form of expectation from Account officers to Supervisors to improve employee performance. If instrumental support is achieved, the performance of the Account Officer will also increase. The following support that the Supervisor must provide is the Role Model, in which a supervisor must demonstrate effective behavior to regulate work balance and outside of work, then the Supervisor must be able to show how to be successful together inside and outside of work. Subsequent support, supervisors must provide benefits for employees and the company jointly. Supervisors are not shy to ask employees for advice in terms of work or outside work, supervisors must also be creative in managing tasks and work to help employees and work teams, and supervisors must manage a team as a form of shared need. This is a form of support that must be given to Account officers to achieve the targets set by the company.

Instrumental Support, role models, and Creativity work-family management have a significant influence on Perceived Supervisor Support and the overall performance of account officers. The findings of this study also agree with the results of the investigation (Talukder and Galang, 2021); (Tarcan et al., 2020); (Tarcan et al., 2021) shows that supervisor support is positively related to employee performance.

This research implies that Instrumental support such as getting directions, advice, suggestions, information, and feedback is highly expected by the Account Officer in overcoming problems that aim to broaden insight and understanding of the problems faced by the Account Officer. To ensure that the company they lead can run dynamically, a supervisor must have specific values that can become a role method. These values must be implementable and applied quickly and understood by subordinates. For example, a supervisor must have integrity, attitude, trustworthiness, sincerity in carrying out his duties, and the main goal is how to run a company for the benefit of the subordinates he leads. Next is Creative work-family management; this can be implemented in the form of initiatives from superiors to structure work aimed at increasing the effectiveness of subordinates outside and inside work. To achieve work effectiveness. The findings in this study have proven that Instrumental Support, role models, and Creativity work family are very effective 
and affect the pattern of Supervisors in acting, and can improve the performance of Account Officers.

Furthermore, the indicators of Social needs, Esteem, actualization, and knowledge strongly influence the Quality of work life. Social needs needed by Account Officers are to prefer more time to enjoy other things in life. Then in the case of Esteem, account officers are more respected in the work environment, and the company always respects professionalism in their respective fields. In terms of actualization, the account officer has realized all the potential to the fullest and is an expert in their respective fields. Account Officers are also willing to learn new knowledge related to work. The findings of this study prove that there is no influence between quality work of life on the performance of account officers, meaning that the Quality of work of life owned by Account Officers has been running well and does not affect performance, account officers are considered to have the ability to balance quality work of life.

The balance of quality work of life obtained by the Account Officer includes having plenty of time to enjoy other things in life to not interfere with routine work. Then the account officer feels valued in the company environment. The people in the workplace also always respect each other and are experts in their respective fields. The account officer also feels that he has taken out all his potential in carrying out his work, then the account officer wants to learn to help work and constantly hone skills to improve work processional. The quality of work-life that already exists in the Account officer is not very significant in improving performance. The findings of this study refute previous research (Sari et al., 2019); (Astuti and Soliha, 2021) which states that there is an influence between the quality of work of life and employee performance.

This finding implies that companies must maintain the quality work of life that has been formed in individual account officers. Because Quality of Work-Life refers to the pleasant or unpleasant state of the work environment for individuals. The main objective of Quality of Work Life is to develop an excellent working environment for employees and production. The main focus of Quality of Work Life itself is that the work environment and all work in it must be by banking developments, Social needs, esteem, actualization, and knowledge must be a severe concern for the company to be maintained.

The following finding is an influence between Perceived Organizational Support on Employee Performance. Perceived Organizational Support indicators have contributed to forming Perceived organizational support and have an effect on improving employee performance; indicators that affect this performance include organizational support for employees where the company must appreciate the contribution made by the Account Officer, the company does not immediately replace the position that has been held Account Officer for a long time, the company has not neglected the interests of its employees, the company always supports if employees get a problem, the company cares about the welfare of employees, the company appreciates the efforts that the Account Officer has made, the company must also care about job satisfaction and must have pride in the Account officer, if the account officer obtains the support it will be able to improve the performance of the account officer. Organizational support will play a significant role in determining the performance of the Account officer.

The results of the study have also explained that Perceived Organizational Support has an effect on employee performance employee (Sulistyan et al., 2021); (Chen et al., 
2020); then, the results of this study do not agree with the results of research by (Sulistyan et al., 2021) which states that the perceived organizational support that is felt directly has not been able to improve employee performance.

This research implies that Perceived Organizational Support is an essential aspect that a company must own. With this aspect, the company can run productively.

There is an influence between Perceived Supervisor Support on Perceived Organizational Support. Supervisors have a strategic position in creating better work arrangements for employees. Where these work arrangements are directly related to organizational policies and procedures. Receiving supervisor support is an essential antecedent for employees experiencing perceived organizational support in the workplace. However, Perceived Supervisor Support and Perceived Organizational Support are essential variables in this study to improve the performance of the Account Officer.

The findings of this study agree with dengan (Sounthary and Vijayalakshmi, 2020), who prove that Perceived Supervisor Support influences Perceived Organizational Support. There is no effect of Quality of Work Life on Perceived Organizational Support. It should be noted that Quality of Work Life is one of the elements that must receive the company's attention so that employees can work comfortably and employees will feel valued. In this finding, of course, the quality of work-life does not influence organizational support. This is because Perceived Organizational Support is not solely influenced by causality because it is not possible for employees individually to influence company policies and rules. Quality of Work Life Account Officer in Islamic Banking is excellent, and there is an indirect effect between Perceived Supervisor Support on Employee Performance mediated by Perceived Organizational Support which means that Perceived organizational support is an intervening variable, it can be concluded that Perceived Organizational Support as Part Mediation it means that without involving Perceived Organizational Support, Perceived Supervisor Support has a significant direct influence on employee performance. Perceived Supervisor Support will directly or indirectly affect the performance of the Account Officer. This is in line with the opinion (Khan et al., 2015), which states that if Perceived Organizational Support is placed on the intervening variable, the effect on performance will be more substantial. However, the effect of Quality of Work Life on Employee Performance mediated by Perceived Organizational Support does not show an indirect effect, and this means that perceived organizational support is not an intervening variable.

The overall implication of this research is that Perceived Supervisor Support, Perceived Organizational Support, and Quality of Work Life are essential points that must be maintained and improved by companies that aim to improve performance. There must be these three variables in individual Account Officers. Companies need to apply the concept of improving performance with perceived supervisor support, perceived organizational support, and quality of work-life so that account officers in Islamic banking can maintain performance. By model, the findings of this research have a novelty from previous studies that Perceived Supervisor Support, Perceived Organizational Support, and Quality of Work Life can improve Account Officer performance. 


\section{CONCLUSION}

This study provides some knowledge in effective employee management processes in general and Islamic banking in particular. First, companies must find ways to increase Perceived Supervisor Support (PSS) and higher Perceived Organizational Support (POS) so that the performance of Account officers increases. Higher PSS and POS levels will be associated with positive work outcomes incredibly adaptive and contextual performance. The results of this study can also help analyze various factors that can cause positive PSS and POS and become important antecedents of employee performance. This research model will help Account Officers meet needs at different levels, leading to positive employee attitudes and behaviors necessary for successful organizational performance.

Acknowledgements. Thank you to the leadership of the Universitas Muhammadiyah Sumatera Utara (UMSU). They have provided both moral and material support through the Internal Research Grant for the 2020/2021 Fiscal Year to complete this research. Thank you to those who have helped and supported this research to completion. Hopefully, this research will provide benefits for the development of science.

\section{REFERENCES}

Abdullah, M. R., and Marican, S. (2020). Supervisory support and organisational citizenship behaviour: the role of self-efficacy as mediator. International Journal of Public Sector Performance Management (IJPSPM), 6(6), 854-875.

Afsar, B., and Badir, Y. (2017). Workplace spirituality, perceived organizational support and innovative work behavior: The mediating effects of person-organization fit. Journal of Workplace Learning, 29(2), 95-109. https://doi.org/10.1108/JWL-112015-0086.

Afzal, S., Arshad, M., Saleem, S., and Farooq, O. (2019). The impact of perceived supervisor support on employees' turnover intention and task performance: Mediation of self-efficacy. Journal of Management Development, 38(5), 369-382. https://doi.org/10.1108/JMD-03-2019-0076.

Almarshad, S. O. (2015). A Measurement Scale for Evaluating Quality of Work Life: Conceptualization and Empirical Validation. Trends in Applied Sciences Research, 10(3), 143-156. https://doi.org/10.3923/tasr.2015.143.156.

Astuti, J. P., and Soliha, E. (2021). The Effect of Quality of Work Life And Organizational Commitment on Performance With Moderation of Organizational Culture. International Journal Of Social And Management Studies (Ijosmas), 02(06), 89-99.

Byrne, Z. S., and Hochwater, W. A. (2008). Perceived organizational support and performance relationships across levels of organizational cynicism. Journal of Managerial Psychology, 23(1), 54-72. https://doi.org/10.1108/02683940810849666.

Chen, T., Hao, S., Ding, K., Feng, X., Li, G., and Liang, X. (2020). The impact of organizational support on employee performance. Employee Relations, 42(1), 166179. https://doi.org/10.1108/ER-01-2019-0079.

Dahkoul, Z. M. (2018). The determinants of employee performance in Jordanian organizations. Pressacademia, $\quad$ 5(1), 11-17. 
https://doi.org/10.17261/pressacademia.2018.780.

Deconinck, J., and Johnson, J. (2009). The effects of perceived supervisor support, perceived organizational support, and organizational justice on turnover among salespeople. Journal of Personal Selling and Sales Management, 29(4), 333-350. https://doi.org/10.2753/PSS0885-3134290403.

Dewi, D. P., Indriati, F., and Soeling, P. D. (2020). Effect of Perceived Organizational Support, Quality Of Work-Life And Employee Engagement on Employee Performance. International Journal of Management (IJM), 11(6), 707-717. https://doi.org/10.34218/IJM.11.6.2020.058.

Dirican, A. H., and Erdi, O. (2020). Linking abusive supervision to job embeddedness: The mediating role of perceived organizational support. Current Psychology, 1-16. https://doi.org/10.1007/s12144-020-00716-1.

Eisenberger, R., and Stinglhamber, F. (2011). Perceived Organizational Support: Fostering Enthusiastic and Productive Employees. American Psychological Association. https://psycnet.apa.org/doi/10.1037/12318-000.

Eisenberger, R., Stinglhamber, F., Vandenberghe, C., Sucharski, I. L., and Rhoades, L. (2002). Perceived supervisor support: Contributions to perceived organizational support and employee retention. Journal of Applied Psychology, 87(3), 565-573. https://doi.org/10.1037/0021-9010.87.3.565.

Farisi, S., and Paramita, D. (2020). The Effect Of Transformational Leadership and Motivation On Employee Performance. International Journal of Economic, Technology and Social Science, 1(1), 129-140. https://doi.org/10.2991/piceeba218.2019.98.

Guo, Y., and Ling, B. (2020). Effects of Leader Motivating Language on Employee Task and Contextual Performance: The Mediating Role of Feedback Quality. Psychological Reports, 123(6), 2501-2518. https://doi.org/10.1177/0033294119862989.

Guterresaa, L. F. D. C., Armanub, and Rofiaty. (2020). The role of work motivation as a mediator on the influence of education-training and leadership style on employee performance. Management Science Letters, 10(7), 1497-1504. https://doi.org/10.5267/j.msl.2019.12.017.

Hermawati, A., and Mas, N. (2017). Mediation effect of quality of worklife, job involvement, and organizational citizenship behavior in relationship between transglobal leadership to employee performance. International Journal of Law and Management, 59(6), 1143-1158. https://doi.org/10.1108/IJLMA-08-2016-0070.

Imran, R. (2011). Mediating Effect of Organizational Climate between Transformational Leadership and Innovative Work Behaviour. Pakistan Journal of Psychological Research.

Imran, R., and Aldaas, R. E. (2020). Entrepreneurial leadership: a missing link between perceived organizational support and organizational performance. World Journal of Entrepreneurship, Management and Sustainable Development, 16(4), 377-388. https://doi.org/10.1108/WJEMSD-10-2019-0077.

Kaya, B., and Karatepe, O. M. (2020). Does servant leadership better explain work engagement, career satisfaction and adaptive performance than authentic leadership? International Journal of Contemporary Hospitality Management, 32(6), 2075-2095. 
https://doi.org/10.1108/IJCHM-05-2019-0438.

Khalid, K. (2020). The Impact of Managerial Support on the Association Between Pay Satisfaction, Continuance and Affective Commitment, and Employee Task Performance. SAGE Open, 10(1), 1-13. https://doi.org/10.1177/2158244020914591.

Khan, S. I., Mahmood, A., Kanwal, S., and Latif, Y. (2015). How perceived supervisor support effects workplace deviance? Mediating role of perceived organizational support. Journal of Commerce and Social Sciences (PJCSS), 9(3), 940-967.

Kurtessis, J. N., Eisenberger, R., Ford, M. T., Buffardi, L. C., Stewart, K. A., and Adis, C. S. (2017). Perceived Organizational Support: A Meta-Analytic Evaluation of Organizational Support Theory. Journal of Management, 43(6), 1854-1884. https://doi.org/10.1177/0149206315575554.

Kusumanegara, I. S., Asmony, T., and Numayanti, S. (2018). Work-family conflict on turnover intention regarding work stress as intervening variable. International Journal of Social Sciences and Humanities, 2(2), 141-154. https://doi.org/10.29332/ijssh.v2n2.153.

Ladebo, O. J. (2008). Perceived supervisory support and organisational citizenship behaviours: Is job satisfaction a mediator? South African Journal of Psychology, 38(3), 479-488. https://doi.org/10.1177/008124630803800303.

Lemeshow, S., Hosmer, J. D. W., Klar, J., and Lwanga, S. K. (1990). Adequacy of Sample Size in Health Stuides. Jhon Wiley \& Sons Ltd.

Lesmana, M. T., and Damanik, F. A. (2022). The Influence of Work Competency and Motivation on Employee Performance. International Journal of Economics, Social Science, Entrepreneurship and Technology (IJESET), 1(1), 83-93. https://doi.org/10.33019/society.v9i1.290.

Meyers, M. C., Kooij, D., Kroon, B., de Reuver, R., and van Woerkom, M. (2020). Organizational Support for Strengths Use, Work Engagement, and Contextual Performance: The Moderating Role of Age. Applied Research in Quality of Life, 15(2), 485-502. https://doi.org/10.1007/s11482-018-9702-4.

Nasution, M. I., and Priangkatara, N. (2022). Work Discipline and Work Motivation on Employee Performance. International Journal of Economics, Social Science, Entrepreneurshipand Technology (IJESET), 1(1), 50-64.

Nauman, S., Zheng, C., and Basit, A. A. (2020). How despotic leadership jeopardizes employees' performance: the roles of quality of work life and work withdrawal. Leadership and Organization Development Journal, 42(1), 1-16. https://doi.org/10.1108/LODJ-11-2019-0476.

Ocampo, R. C. De, Danao, H. N., and Peña, A. M. (2018). The Relationship Of Perceived Organizational Support And Perceived Supervisor Support To Work Engagement Among BPO-RPO Employees. International Journal of Advanced Research and Publications, 2(9), 97-105.

Perangin-Angin, M. R., Lumbanraja, P., and Absah, Y. (2016). The Effect Of Quality Of Work Life On Employee Performance With Job Satisfaction As An Intervening Variables. Management Analysis Journal, 5(4), 315-324.

Potipiroon, W., and Faerman, S. (2020). Tired from Working Hard? Examining the Effect of Organizational Citizenship Behavior on Emotional Exhaustion and the Buffering Roles of Public Service Motivation and Perceived Supervisor Support. Public 
Performance and Management Review, 43(6), 1260-1291. https://doi.org/10.1080/15309576.2020.1742168.

Purwaningrum, E. K., Suhariadi, F., and Fajrianthi. (2020). Participation and Commitment to Change on Middle Managers in Indonesia: The Role of Perceived Organizational Support as Mediator. Global Business Review, 1-18. https://doi.org/10.1177/0972150919892371.

Ridwan, M., Mulyani, S. R., and Ali, H. (2020). Improving employee performance through perceived organizational support, organizational commitment and organizational citizenship behavior. Systematic Reviews in Pharmacy, 11(12), 839-849. https://doi.org/10.31838/srp.2020.5.123.

Rivai, H. A., and Lukman, S. (2019). The Mediating Role of Job Satisfaction on The Relationship Between Perceived Organizational Support and Job Performance. Business \& Management Studies: An International Journal, 7(2), 1-17.

Rubel, M. R. B., and Kee, D. M. H. (2013). Perceived Support and Employee Performance: The Mediating Role of Employee Engagement. Life Science Journal, 3(19), 92-99.

Santoso, A., Kessi, A. M. P., and Anggraeni, F. S. (2020). Hindrance of quality of knowledge sharing due to workplace incivility in Indonesian pharmacies: Mediating role of co-worker and organizational support. Systematic Reviews in Pharmacy, 11(2), 525-534. https://doi.org/10.5530/srp.2020.2.80.

Sari, N. P. R., Bendesa, I. K. G., and Antara, M. (2019). The Influence of Quality of Work Life on Employees' Performance with Job Satisfaction and Work Motivation as Intervening Variables in Star-Rated Hotels in Ubud Tourism Area of Bali. Journal of Tourism and Hospitality Management, 7(1), 74-83. https://doi.org/10.15640/jthm.v7n1a8.

Shahzad, I. A., Farrukh, M., Kanwal, N., and Sakib, A. (2018). Decision-making participation eulogizes probability of behavioral output; job satisfaction, and employee performance (evidence from professionals having low and high levels of perceived organizational support). World Journal of Entrepreneurship, Management and Sustainable Development, 14(3), 321-339. https://doi.org/10.1108/wjemsd-012018-0006

Soelton, M., Ramli, Y., Ali, A. J., Arief, H., Saratian, E. T. P., and Pasaribu, E. (2020). To Imply the Organizational Citizenship Behavior. International Journal of Business, Economics and Law, 21(5), 70-82.

Sounthary, T. G., and Vijayalakshmi. (2020). Impact of Perceived Supervisor Support and Perceived Organizational Support on Organizational Citizenship Behaviour. International Journal of Management (IJM), 11(11), 501-508. https://doi.org/10.34218/IJM.11.11.2020.048.

Sulistyan, R., Paramita, R., Setyobakti, M., Rizal, N., and Lukiana, N. (2021). Perceived Organizational Support on Employee Performance: The Mediating Effect of Job Stress. Proceedings of the 1st International Conference on Social Science, Humanities, Education and Society Development (ICONS), 1-10. https://doi.org/10.4108/eai.30-11-2020.2303710.

Tabiu, A., Pangil, F., and Othman, S. Z. (2020). Does Training, Job Autonomy and Career Planning Predict Employees' Adaptive Performance? Global Business Review, 21(3), 713-724. https://doi.org/10.1177/0972150918779159. 
Talukder, A. K. M. M. H., and Galang, M. C. (2021). supervisor support for employee performance in Australia: mediating role of work-life balance, job, and life attitude. Journal of Employment Counseling, 58, 1-21.

Tarcan, G. Y., Erigüç, G., Kartal, N., Koca, G. Ş., and Karahan, A. (2020). The effect of mushroom management style and perceived supervisor support on employee performance: 'An application with university hospital employees.' International Journal of Health Planning and Management, December 2020, 1-14. https://doi.org/10.1002/hpm.3102.

Tarcan, G. Y., Erigüç, G., Kartal, N., Koca, G. Ş., and Karahan, A. (2021). The effect of mushroom management style and perceived supervisor support on employee performance: "An application with university hospital employees." Int J Health Plann, 36(2), 532-544. https://doi.org/10.1002/hpm.3102.

Thakur, R., and Sharma, D. (2019). A Study of Impact of Quality of Work Life on Work Performance. Management and Labour Studies, 44(3), 326-344. https://doi.org/10.1177/0258042x19851912.

Zhang, J. A., Chen, G., O'Kane, C., Xiang, S., and Wang, J. (2020). How employee exploration and exploitation affect task performance: The influence of organizational competitive orientation. International Journal of Human Resource Management, $0(0)$, 1-34. https://doi.org/10.1080/09585192.2020.1745866. 